\title{
Econometric Analysis of the Effect of Changes in Price on Consumption Pattern of Petrol, Rice and Bean in Owerri City, Imo State, Nigeria
}

\author{
*NWOSU, UI; VINCENT, U
}

\author{
Department of Statistics, Federal University of Technology, Owerri, P.M.B. 1526, Owerri, Imo State, Nigeria \\ *Corresponding Author Email: nwosuugochinyere@yahoo.com; Tel: +2347061118381
}

\begin{abstract}
It was hypothesized that changes in price could affect the consumption pattern of petrol, rice and bean, their status as basic needs notwithstanding. To test this hypothesis, primary data were generated, subjected to econometric model and analyzed. Two-hundred residents of different income groups who live in Owerri city, Imo State, Nigeria and have used petrol, rice and bean for at least ten years and were not less than thirty-one years old were sampled using standard method. The pretest result of questionnaire validity and reliability was $r=0.726$ and this indicates high reliability. A total of $90 \%$ strongly agreed and agreed that prices of petrol, rice and bean are unstable in Owerri City, Imo State, Nigeria. The results indicate that $70 \%$ of the consumers strongly agreed and agreed that price affects consumption of the products irrespective of need. This was a significant observation too. In the study, availability of petrol, rice and bean affected consumption in an urban environment.Grain quality was found a strong determinant of consumption of rice and bean in the city. There was a positive and non-significant relationship between price and consumption of petrol, rice and bean and this shows that price is not the most important determinant of consumption of all commodities. Necessity was more important than price in consumption of petrol, rice and bean in the city of Owerri, Imo State, Nigeria. These findings are useful to econometricians, policymakers, governments and households.
\end{abstract}

DOI: $\underline{\text { https://dx.doi.org/10.4314/jasem.v24i8.15 }}$

Copyright: Copyright (C) 2020 Nwosu and Vincent. This is an open access article distributed under the Creative Commons Attribution License (CCL), which permits unrestricted use, distribution, and reproduction in any medium, provided the original work is properly cited.

Dates: Received: 30 May 2020; Revised: 03 July 2020; Accepted: 05August 2020

Keywords: Basic needs, Econometric model, Income groups, High reliability, Grain quality.

Price is the principal determinant of consumption patterns in the society (Green et al., 2013; Piligrimiene et al., 2020). It has been noted that household food consumption pattern in Nigeria has experienced dramatic changes in recent times (Obayelu et al., 2009). The persistent rise in prices of commodities in Nigeria is strongly related to government and the manipulation of petroleum products, especially petrol. Petrol has very powerful influence that shortages and changes in price disrupt essential transactions and changes economic situation (Ocheni, 2015). Increases in prices of petroleum products have culminated in inflation, inequitable distribution of income and high cost of living (Arinze, 2011; Ndubueze-Ogaraku, 2016). This has incontrovertibly resulted to instability in the prices of goods and services in almost all sectors of the economy. Petrol, rice and bean constitute basic needs of the people and most economic activities rely on petrol. Rice and bean are palatable, nutritious and used industrially in the manufacture of other products and thus are critical in domestic, national and international food security (Gnanamanickam, 2009; Lopes et al., 2016; Nwosu et al., 2016). High commodity prices have bad consequences on the diet, health and total existence of citizens, particularly the poor (Martinez-Lacoba et al., 2020). The global food crises of 2007 to 2008 attracted international attentions to effect of changes in food price on nutrition, health and consumption pattern (NdubuezeOgaraku, 2016). From the international point of view, there is evidence that rise in price adversely affects dietary diversity and quality; causing disorderliness in the country, and wealth less individuals are mostly affected (Mazzocchi et al., 2012). Developed countries are implementing felicitous fiscal measures with the capacity to change the relative price of foods in order to sustain healthy diets and promote better livelihood (Smed, 2012). Unfortunately, this is not the case in Nigeria and therefore, it is necessary to perform routine analysis of the effects of changes in price on the consumption pattern of the people in order to create awareness and identify factors of importance. Studies on consumption patterns are necessary because it shows estimates of how consumption is affected by changes in price, income and taxation policies (Dunnem and Edkins, 2005). Leaders and policymakers have shown serious concerns about the effects sharp price increases in food commodities can have on welfare of the people 
and food security. Aliyu and Amadu (2017) stressed that in Nigeria, per-capita growth of production of major foods is not enough to meet the demands of ever increasing urbanization and population. This creates the need to perform routine analysis in order to identify factors of importance. The removal of petrol subsidy and economic recession led to alarming increase in the price of commodities in Nigeria. Till date, many Nigerians are yet to recover. Petrol, rice and beans appear indispensable in the survival of Nigerians. Therefore, the objective of this study is to determine the impact of changes in price on consumption pattern of petrol, rice and bean in the study area.

\section{MATERIALS AND METHODS}

This study was carried out in Owerri city, Imo State, Nigeria in 2019. The population of Imo was projected as 5,408, 800 in 2016 (National Population Commission of Nigeria and National Bureau of Statistics). Owerri city is situated in the cities place category with global positioning system coordinates of $5^{\circ} 28^{\prime} 34.7160^{\prime \prime} \mathrm{N}$ and $7^{\circ} 1^{\prime} 33.0708^{\prime \prime} \mathrm{E}$.

The latitude is 5.476310 and the longitude is 7.025853 (https:/www.latlong.net/place/owerri-imonigeria-13046.html). Primary data were sufficiently generated for the investigation. Well-structured questionnaire was self-administered randomly to twohundred residents who live in Owerri city and are not less than thirty-one years old. The sampled population must have used petrol, rice and bean for at least 10 years. Petrol, rice and bean were chosen because of their importance. The questionnaire was validated and the reliability was tested using Cronbach Alpha coefficient (Robinson, 2009; Feng and Yamat, 2019). The questionnaires were completed on the spot and were returned immediately.

The questionnaire provided answers to the research questions and hypothesis. The null hypothesis $\left(\mathrm{H}_{0}\right)$ tested states that changes in price do not have any effect on consumption rate of petrol, rice and bean in Owerri City, Imo State, Nigeria. Whereas, the alternative hypothesis $\left(\mathrm{H}_{1}\right)$ states that changes in price have an effect on consumption rate of petrol, rice and bean in Owerri City, Imo State, Nigeria. The level of significance considered was 0.05 . The decision rule was to reject the null hypothesis if the pvalue is less than the level of significance and accept if otherwise. To test this hypothesis and check whether consumption rate remains unaffected irrespective of changes in price, multiple regression econometric model was applied as follows:
$Y_{i}=\beta_{0}+\beta_{1} X_{1 i}+\beta_{2} X_{2 i}+\beta_{3} X_{3 i}+u_{i}$ $i=1,2,3, \mathrm{n} \quad(1)$

From theoretical perspective, the model states that consumption rate depends on price of petrol, rice and bean. The consumption pattern is weighted combination of petrol, rice and bean. The weights $\beta_{1}, \beta_{2}$ and $\beta_{3}$ are the respective effects of a unit change in the increase in the prices of these basic items on the consumption rate through price change. Thus consumption rate is expressed as follows;

Consumption Pattern $=\beta_{0}+\beta_{1}$ Petrol Price +

$\beta_{2}$ Rice Price $+\beta_{3}$ Beans Price + Error

Where, Error $=$ Consumption Pattern

$-\beta_{0}-\beta_{1}$ Petrol Price - $\beta_{2}$ Rice Price $-\beta_{3}$ Bean

Price

On the estimation, the intercept $\left(\beta_{0}\right)$ and slope coefficient $\left(\beta_{1}, \beta_{2}, \beta_{3}\right)$ are expected prior to having a positive sign, $\beta_{i}(\mathrm{i}=0,1,2,3)>0$, implying that consumption rate is expected to correlate positively with the increase in prices of petrol, rice and bean while error is the random disturbances in the model. The model is based on some basic assumptions about the regressors and the error terms.

The assumptions concerning the error term;

i. $\quad \mu$ is a random vector

ii. $\quad E(\mu)=0$

iii. $\quad E\left(\mu^{\prime} \mu\right)=\sigma^{2} I_{n} \quad$ that is $E\left(\mu_{i} \mu_{j}\right)= \begin{cases}\sigma^{2} & i=j \\ 0 & i \neq j\end{cases}$

iv. $\quad \mu \sim \operatorname{NID}\left(0, \sigma^{2} I_{n}\right)$

The assumptions concerning the explanatory variables;

i. The values taken by $\mathrm{X}$ variables are fixed in repeated sampling.

ii. The non-stochastic regressors (X) and the stochastic error terms are uncorrelated. That is $E\left(X^{\prime} \mu\right)=0$

iii. The regressors are linearly independent, hence $\left|X^{\prime} X\right| \neq 0$, which follows that $\mathrm{X}$ matrix has rank $r=(k-1)<n$ 
Statistical Package for the Social Sciences (SPSS) version 23.0 was the software used to run the analysis. The normal percentage probability was plotted against the residual for the model. The residuals are $e_{i j k}=y_{i j k}-\hat{y}_{i j k}$; where $\hat{y}_{i j k}$ is the average observation in the (ij)th cell. If the points follow approximately along the diagonal line, it is concluded that the data are approximately normally distributed. If the points have a distinct curvature, the data are likely skewed. If the points follow S-curve shape, data are likely uniform. Homoscedasticity test (using Levene's test of constant variance) was also done to determine the suitable model to be applied.

\section{RESULTS AND DISCUSSION}

In the study, the result of questionnaire validity and reliability test was $r=0.726$. Figure 1 shows the result of the probability plot of the residual during investigations on normality of data collected in Owerri city, Imo State, Nigeria during August, 2019. It was observed that the points in the probability plot follow approximately along the diagonal line.Table 1 shows the result of homoscedasticity test of data collected in Owerri City in August, 2019. The consumption pattern passed the assumption of constant variance and Figure 2 shows the distribution plot. Table 2 presents the gender of the respondents in Owerri city, Imo State, Nigeria who have consumed petrol, rice and beans for a minimum period of 10 years. The results showed a total of two hundred respondents. Eighty respondents which represented $40 \%$ of sampled population were males while one hundred and twenty respondents which represented $60 \%$ of the population were females. Table 3 shows the age grade of respondents. Ages 31-40 years were the lowest age grade in the survey and constituted $20 \%$ of the sample whereas, $>60$ years of age was the highest age grade and constituted $20 \%$ of the sample too. Table 4 shows the marital status of sampled population. Forty respondents representing $20 \%$ were single while 160 individuals $(80 \%)$ were married. Table 5 presents information on the highest educational qualification of sampled population. A total of six respondents (3\%) have First School Leaving Certificate as their highest qualification. Thirty individuals (15\%) have the West African Senior School Certificate as highest qualification. Fifty respondents which represent $25 \%$ of the sampled population possess the Ordinary National Diploma or Nigerian Certificate of Education or Advance Level Certificate. Seventy respondents (35\%) hold Bachelor's degree or Higher National Diploma while the remaining 22\% (44 respondents) possess postgraduate degree. Table 6 shows the occupational distribution of the respondents. One hundred respondents $(50 \%)$ worked in the public sector, 50 respondents $(25 \%)$ worked in the private sector and 50 respondents (25\%) were self-employed. Figure 3 summarizes the percentage responses of respondents that prices of petrol, rice and bean are unstable in Owerri City, Imo State, Nigeria. A total of $90 \%$ strongly agreed and agreed to this assertion and this is a significant observation. Figure 4 shows the percentage responses of respondents that price affects consumption of petrol, rice and bean in Owerri City, Imo State, Nigeria and $70 \%$ of the sampled population strongly agreed and agreed. This is significant too. Figure 5 presents the percentage response of the respondents that availability of petrol, rice and bean affects the consumption of the products in Owerri City, Imo State, Nigeria. A total of $84 \%$ strongly agreed and agreed to this assertion. Figure 6 shows the percentage response of respondents that grain quality affects consumption of rice and bean in Owerri City, Imo State, Nigeria and $90 \%$ of the respondents strongly agreed and agreed that grain quality affects consumption rate. The analysis of variance testing whether changes in price affect the consumption of petrol, rice and bean is shown in Table $7 \mathrm{a}$ and Table $7 \mathrm{~b}$ presents the model summary. The correlation coefficient $\mathrm{R}$ of consumption of petrol, rice and bean and price was 0.407. The relationship is positive but was not significant.

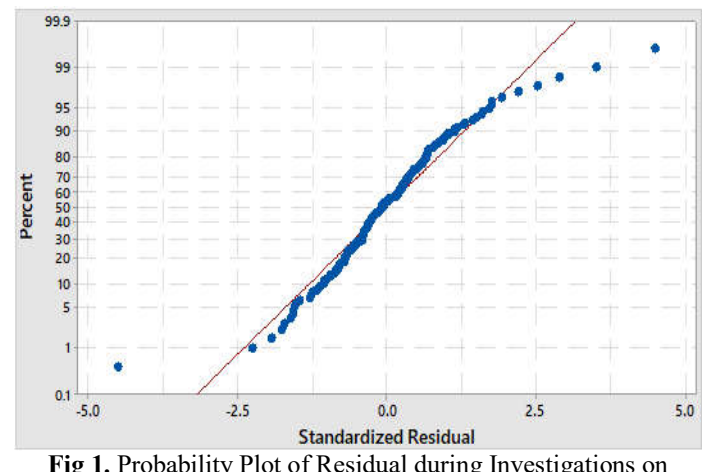

Fig 1. Probability Plot of Residual during Investigations on Normality of Data Collected in Owerri City during August, 2019.

Table 1. Result of Homoscedasticity Test of Data Collected in Owerri City, Imo State, Nigeria in 2019.

\begin{tabular}{cllll}
\hline & & $\begin{array}{l}\text { Levene } \\
\text { Statistic }\end{array}$ & Df & P-value \\
\hline Consumption & & \\
pattem & 5.305 & 2 & 0.063 \\
& Based on Mean & 1.929 & 2 & 0.147 \\
& Based on Median & 1.929 & 2 & 0.148 \\
& Based on trimmed mean & 5.158 & 2 & 0.063 \\
\hline
\end{tabular}

The analysis of result of questionnaire validity and reliability showed high reliability and this is supported by Hinton et al. (2004), Straub et al. (2004) and Feng and Yamat (2019). 


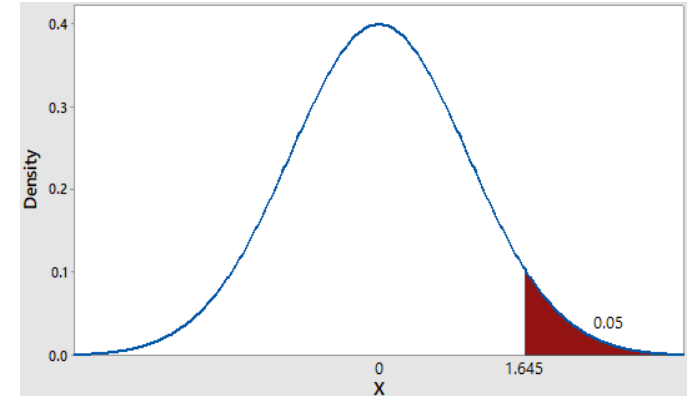

Fig 2. Distribution Plot on Normality of Data Collected in Owerri City, Imo State, Nigeria during August 2019.

Changes in prices of petrol rice and bean in Nigeria have continued to attract widespread attention (Ocheni, 2015; Orlu, 2017; Nwosu et al., 2016).The consumption pattern of petrol, rice and bean has faced dramatic changes even in recent times and therefore estimates of how their consumption is affected by changes in price is necessary (Dunnem and Edkins, 2005). Hike in the prices of petrol, rice and bean could incontrovertibly lead to food security problems and poverty. The economic recession experienced by Nigeria has greatly affected all sectors of the economy and part of the consequence is that the consumption pattern of many Nigerians is adversely affected. From the analysis of the probability plot of the residual and the distribution

plot, the data were approximately normally distributed and this provided part of the justification for its use. In the study, the consumption pattern passed the assumption of constant variance since the $\mathrm{p}$-value 0.063 is greater than the probability value of 0.05 .

Table 2. Gender of Respondents in Owerri City, Imo State, Nigeria

\begin{tabular}{lll} 
& \multicolumn{2}{c}{ during 2019.} \\
\hline Sex & Frequency & Percentage constitution \\
\hline Male & 80.0 & 40.0 \\
Female & 120.0 & 60.0 \\
Total & 200.0 & 100 \\
\hline \multicolumn{2}{c}{ Source: } & Authors computation from questionnaire.
\end{tabular}

Table 3. Age Grade of Respondents in Owerri City, Imo State,

\begin{tabular}{lll}
\multicolumn{3}{c}{ Nigeria during 2019.} \\
\hline Age ( years ) & Frequency & Percentage constitution \\
\hline $31-40$ & 40.0 & 20.0 \\
$41-50$ & 60.0 & 30.0 \\
$51-60$ & 60.0 & 30.0 \\
$>60$ & 40.0 & 20.0 \\
Total & 200.0 & 100.0 \\
\hline \multicolumn{2}{r}{ Source: Authors computation from questionnaire. }
\end{tabular}

Table 4: Marital Status of Respondents in Owerri City, Imo State,

\begin{tabular}{lll} 
& \multicolumn{2}{c}{ Nigeria during 2019.} \\
\hline Marital status & Frequency & Percentage constitution \\
\hline Single & 40.0 & 20.0 \\
Married & 160.0 & 80.0 \\
Total & 200.0 & 100.0 \\
\hline \multicolumn{2}{c}{ Source: Authors computation from questionnaire. }
\end{tabular}

Table 5: Highest Educational Qualification of Respondents in Owerri City, Imo State, Nigeria during 2019.

\begin{tabular}{lll}
\hline Qualification & Frequency & Percentage constitution \\
\hline First School Leaving Certificate (FSLC) & 6.0 & 3.0 \\
West African Senior School Certificate (WASSC) & 30.0 & 15.0 \\
OND*/NCE**/Advance Level & 50.0 & 25.0 \\
Bachelor's degree/Higher National Diploma & 70.0 & 35.0 \\
Postgraduate degree & 44.0 & 22.0 \\
Total & 200.0 & 100.0 \\
\hline National Diploma; ** Nigerian Certificate of Education; Source: Authors computation from questionnaire.
\end{tabular}

The biometrics of sampled population indicates that the consumers of the products in the city were of different gender, age, marital status and had different educational background. The variation encountered is interesting and ultimately reduced bias in the study. They had used the products for at least ten years and so data obtained from them are reliable. This is because experience is vital in reliability of information supplied (Katarzyna and Shaofeng, 2018). The results further revealed that prices of petrol, rice and bean are unstable in the area and this significant observation has serious economic implications. Instability in the price of petrol, rice and bean disorganises many Nigerian households, causes disorderliness in the feeding pattern of the people and ultimately impoverishes the citizenry. Evidences (Ocheni, 2015; Orlu, 2017) have shown that when the price of petrol increases, even when it is marginal, cost of transportation becomes too exorbitant. This in turn affects every other activity in the country and prices of other commodities including rice and bean become adversely affected. Many families cannot afford to pay school fees and house rents when this occurs. Price instability and impact on economic growth has continued to receive controversial attention (Akalpler and Nuhu, 2018). Some legislators and economists advice that price instability has the capacity to stimulate domestic production and development (Olomola, 2006; Akpan, 2009) whereas earlier report by Darby (1982) maintains that price instability restricts development. It is clear that the immediate consequence of price instability is disorderliness and many households and businesses cannot immediately adjust. The study also revealed that price affects consumption of petrol, rice and bean in Owerri city, Imo State, Nigeria. This has shown that even in the city where many residents are wellto-do individuals, price is a strong determinant of 
consumption. Our study revealed that availability of the products affects consumption rate. This is in line with normal economic attitude where the propensity to consume tends to be higher when the product is abundantly available. We also found that grain quality is an important factor of consumption of rice and bean in the city.

Table 6: Occupational Distribution of the Respondents in Owerri City, Imo State, Nigeria during 2019.

\begin{tabular}{lll}
\hline $\begin{array}{l}\text { Occupation } \\
\text { category }\end{array}$ & Frequency & $\begin{array}{l}\text { Percentage } \\
\text { constitution }\end{array}$ \\
\hline Public sector & 100.0 & 50.0 \\
Private sector & 50.0 & 25.0 \\
Self-employed & 50.0 & 25.0 \\
Total & 200.0 & 100.0 \\
\hline Source: Authors computation from questionnaire.
\end{tabular}

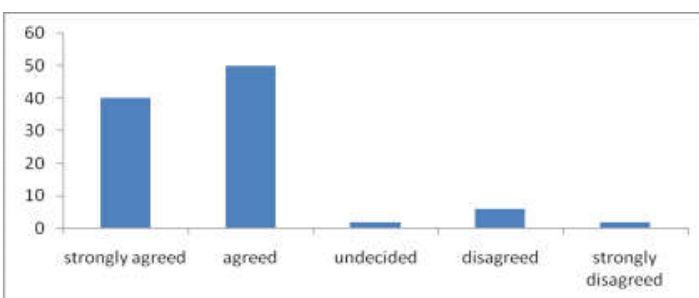

Fig 3. Percentage Responses of Respondents that Prices of Petrol, Rice and Bean are Unstable in Owerri City, Imo State, Nigeria.

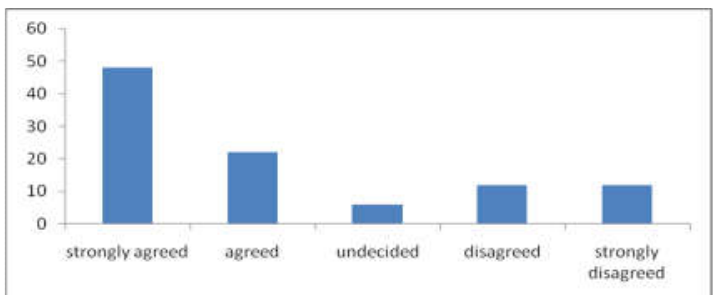

Fig 4. Percentage Responses of Respondents that Price Affects Consumption of Petrol, Rice and Beans in Owerri City, Imo State, Nigeria.

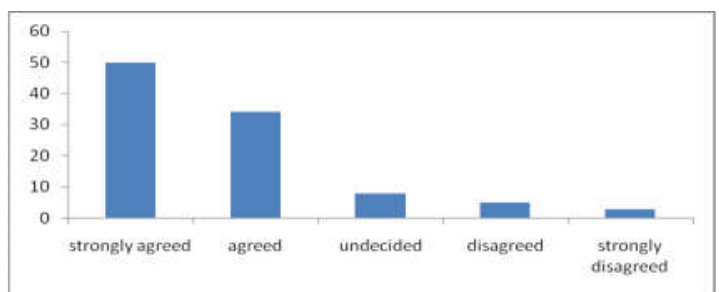

Fig 5. Percentage Response of the Respondents that Availability of Petrol, Rice and Bean Affects the Consumption of the Products in Owerri City, Imo State, Nigeria.

In other words, the sampled population would consume more, when available grains are of good quality. This agrees with the issue of visual appeal in both local and international markets.

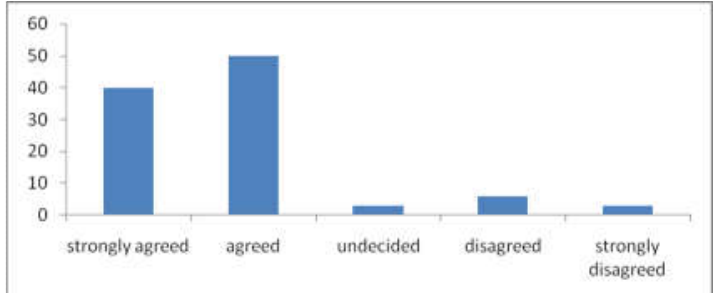

Fig 6. Percentage Response of Respondents that Grain Quality Affects Consumption of Rice and Bean in Owerri City, Imo State, Nigeria

Table 7a. Analysis of Variance for Testing Whether Changes in Price Affect the Consumption of Petrol, Rice and Bean in Owerri City, Imo State, Nigeria during 2019.

\begin{tabular}{llllll}
\hline Source & DF & Adj SS & Adj MS & F-Value & P-Value \\
\hline Regression & 3 & 0.0856 & 0.02854 & 0.17 & 0.915 \\
Price of petrol & 1 & 0.0447 & 0.04468 & 0.27 & 0.604 \\
Price of rice & 1 & 0.0152 & 0.01524 & 0.09 & 0.762 \\
Price of bean & 1 & 0.0369 & 0.03694 & 0.22 & 0.638 \\
Error & 196 & 32.5059 & 0.16585 & & \\
Total & 199 & 32.5915 & & & \\
\hline
\end{tabular}

\begin{tabular}{llll}
\multicolumn{4}{c}{ Table 7b. Model Summary } \\
\hline S & R-sq & R-sq (adj) & R_sq (pred) \\
\hline 0.407 & $0.26 \%$ & $0.00 \%$ & $0.00 \%$ \\
\hline
\end{tabular}

According to Lale (2002) bad quality grain is often neglected in markets and it faces lower attraction and consumption. In econometrics, this has some implications since the food security of the products have been compromised. The result of the correlation coefficient implies that consumption of petrol, rice and bean is not significantly affected by changes in price. This is probably because; the concerned items constitute basic needs of life. It is now obvious why increases in price did not reduce consumption of the products. Therefore, this study has revealed that increase in the price of basic needs does not ultimately lead to reductions in consumption rate.

Conclusion: The present study reveals that price is not the most important determinant of consumption of all commodities. Necessity was more important than price in consumption of petrol, rice and bean in the city of Owerri, Imo State, Nigeria (an urban environment). We recommend that basic items of need should be subsidized by the government to ensure stable and affordable prices. Individuals should involve in active occupations to ensure they have stable sources of income. Nigerians should reconsider agriculture as major source of income.

\section{REFERENCES}

Akalpler, E; Nuhu, AB (2018). The impact of oil price instability on economic growth: evidence from Nigeria. J. Bus. Econ. Manag. Res. 1(1): 39 - 53 
Akpan, EO (2009). Oil price shock and Nigeria's macroeconomy. J. Econ. 4(2): 12 - 19.

Aliyu, AA; Amadu, L (2017). Urbanization, cities and health: the challenges to Nigeria- a review. Ann. Afr. Med. 16(4): $49-158$

Arinze, PE (2011). The impact of oil price on the Nigerian economy.www.transcampus.org/journals.www.ajol. info/journals/jorind. JORIND 9(1).

Daley, M (1982). The price of oil and world inflation and recession. Am. Econ.Rev. 72(4): 738 - 751.

Dunnem, P; Edkins, B (2005). The demand for food in South Africa. Economics Society SouthAfrica Conference, Durban.

Feng, CK; Yamat, H (2019). Testing on the validity and reliability of task based language teaching questionnaire. IJARBSS 9(12): $474-485$

Gnanamanickam, SS (2009). Rice and its importance to human life. Progress Bio. Control 8: 1-11.

Green, R; Cornelsen, L; Dangour, AD; Turner, R; Shankar, B; Mazzocchi, M; Smith, RD (2013). The effect of rising food prices on food consumption: systematic review with meta-regression. BMJ 346: $1-9$.

Hanson, K; Andrews, M (2008). Rising food prices take a bite out of food stamp benefits, EIB41. Washington, DC: USDA, ERS.http://www .ers.usda.gov/publications/eib- economicinformation-bulletin/eib41.aspx.

Hinton, PR; Brownlow, C; MC Murray, I; Cozens, B (2004). SPSS Explained. East Sussex, England, Routledge Inc.

Katarzyna, T; Shaofeng, L (2018). Reliability of information systems in organization in the context of banking sector: empirical study from Poland. Cogent Bus. Manag. 5:1

Lale, NES (2002). Stored Product Entomology and Acarology in Tropical Africa. Mole Publication.

Lopes, LM; Araújo, AEF; Santos, ACV; Santos, VB; Sousa, AH (2016). Population development of Zabrotes subfasciatus (Coleoptera: Chrysomelidae) in landrace bean varieties occurring in Southwestern Amazonia. J. Econ. Entomol. 109(1): $467-471$.

Mazzocchi, M.; Shankar, B; Traill, WB (2012). The development of global diets since ICN 1992: influences of agri-food sector trends and policies. FAO Commodity and Trade Policy Working Paper No 34, FAO, 2012.

Martinez-Lacoba, R; Pardo-Garcia, I; Amo-saus, E.; Escribano-Sotos, F (2020). Social determinants of food group consumption based on Mediterranean diet pyramid: a cross-sectional study of University students. PLoSONE 15(1): e0227620.

Ndubueze-Ogaraku, ME; Oyita, GE; Anyanwu, SO (2016). Analysis of household consumption expenditure on selected staple foods in Ika, North East Local Government Areas of Delta State, Nigeria. DRJAFS4 (10): 300 - 307.

Nwosu, LC; Zakka, U; China, BO; Ugagu, GM (2018). Arsenic exposure from bean seeds consumed in Owerri Municipal, Imo State, Nigeria: Can Insect Pest Detoxify the Metalloid during Infestation? JJBS 11(1): 113 - 116.

Obayelu, AE; Okoruwa, VO; Oni, OA (2009). Analysis of rural and urban households' food consumption differential in the North-central, Nigeria: A microeconometric approach. JDAE 1(2): $18-26$.

Ocheni, SI (2015). Impact of fuel price increase on the Nigerian Economy. Mediterr. J. Soc. Sci. 6(1): 560 -569 .

Olomola, PA (2006). Oil price shocks and aggregate economic activity in Nigeria. Afri. J. Econ. Bus. Rev. 4(2): $40-45$.

Orlu, RN (2017). The impact of domestic pricing of petrol on economic growth of Nigeria (1970-2013). Glob. J. Soc. Sci. 16: $1-8$.

Piligrimiene, Z; Zukauskaite, A; Korzilius, H; Banyte, J; Dovaliene, A (2020). Internal and external determinants of consumer engagements in sustainable consumption. Sustainability 12: 1349 1369.

Robinson, J (2009). Triandis theory of interpersonal behaviour in understanding software privace behaviour in the South African context. Masters degree, University of the Witwatersrand.

Smed, S (2012). Financial penalties on foods: the fat tax in Denmark. Nutr. Bull. 37: 142 - 147.

Straub, D; Boudreau, MC; Gefen, D (2004). Validation guidelines for IS prositivist research. Commun. Assoc. Inf. Syst. 13: $380-427$ 